\title{
Rock debris in an Antarctic ice shelf
}

\author{
K.W. NICHOLLS, ${ }^{1}$ H.F.J. CORR, ${ }^{1}$ K. MAKINSON, ${ }^{1}$ C.J. PUDSEY ${ }^{2}$ \\ ${ }^{1}$ British Antarctic Survey, Natural Environment Research Council, Cambridge, UK \\ E-mail: kwni@bas.ac.uk \\ ${ }^{2}$ Department of Geography, University of Dundee, Dundee, UK
}

\begin{abstract}
We have discovered a band of stones and coarse sand in the Ronne Ice Shelf, Antarctica, some $60 \mathrm{~m}$ above the ice shelf's base, $40 \mathrm{~km}$ from its seaward edge and $420 \mathrm{~km}$ from the point where the ice originally went afloat. A study of ice-sounding radar data from across the Ronne Ice Shelf has revealed other areas likely to contain debris in significant quantities. It appears that basal debris at the margins of ice streams feeding the ice shelf can be buried in the ice shelf by sea water freezing-on at the ice-shelf base. These findings are evidence for a mechanism active in a present-day ice-sheet/shelf system, which enables icebergs to transport large volumes of ice-rafted debris, and which also provides a potential mechanism for the formation of ice rises near ice fronts. We anticipate that a seismics study of debris melted from the ice shelf and deposited beneath will provide a valuable control on the history of ice-shelf-ocean interactions.
\end{abstract}

\section{INTRODUCTION}

When large marine-based ice sheets reach the coast they often drain via fast-flowing ice streams into floating ice shelves. Melt rates in the vicinity of the deep ice near grounding lines of Antarctic ice shelves tend to be at least an order of magnitude higher than the average across the ice shelf (Rignot and Jacobs, 2002), so any debris near the ice base would be expected to melt out very soon after going afloat in the ice shelf. For example, ice discharged from Rutford Ice Stream into the Ronne Ice Shelf has a $760 \mathrm{~km}$ journey to the ice front, and within the first $200 \mathrm{~km}$ of that journey the ocean is estimated to melt a $900 \mathrm{~m}$ thick layer of ice from the ice-shelf base (Jenkins and Doake, 1991).

The general rule that thick ice shelves are devoid of rock material presents difficulties in explaining the distribution of ice-rafted debris (IRD) over the North Atlantic that constitutes Heinrich events. Hulbe (1997) suggested a mechanism that would allow debris to remain buried in ice shelves long enough to be rafted out over the North Atlantic after an iceshelf disintegration event. In this paper, we show evidence for that process in the Ronne Ice Shelf and identify a possible signature for IRD in ice-sounding radar data.

\section{OBSERVATIONS}

In January 2003 a device to recover ice cores using a hotwater drilling technique was tested at a site on the Ronne Ice Shelf. The site (Fox 4; Fig. 1) was about $40 \mathrm{~km}$ from the ice front, and $420 \mathrm{~km}$ downstream of where the ice first went afloat. When the drill was retrieved from $310 \mathrm{~m}$ depth it was found to contain no ice core, but to be covered in coarse sand, with the core catchers on the drill head jammed open by small stones (Fig. 2). A clean ice core had previously been recovered from $210 \mathrm{~m}$ depth. While using a standard nozzle to deepen the borehole to provide access to the sea, the tension on the drill string was erratic, indicating a substantial amount of debris at the bottom of the hole.

Unlike most glacial debris, the recovered sediment is texturally and compositionally mature. The sample (30 g total) comprises $1.3 \%$ gravel, $92.8 \%$ sand and $5.9 \%$ mud. As the sample was not recovered in the form of a core, but had been substantially washed during its passage through $250 \mathrm{~m}$ of water-filled borehole, much of the finest fractions will have been lost. The rounded gravel grains include five quartzites, two feldspathic sandstones and three lithic sandstones (Fig. 2a). The sand is well sorted and fine, with a mode at 2.9 phi (Fig. 2b); it is dominated by quartz, with some $10 \%$ of feldspar and metasedimentary grains. Most of the coarse sand grains are subrounded to rounded, and scanning electron microscopy reveals common edge abrasion (Fig. 2c). Some grains are well rounded and frosted.

As the largest grain is only $8 \mathrm{~mm}$ long it is inappropriate to analyse the debris for striations or clast faceting, and most shape classifications (Benn and Ballantyne, 1994) have been designed for glacial clasts rather than matrix. This sediment is interpreted as subglacial debris mainly because of its great depth within the ice shelf and the absence of any source of supra- or englacial sediment upstream; the only known outcrops are the tiny Haag Nunataks $\left(77^{\circ} 5^{\prime} \mathrm{S}, 78^{\circ} 30^{\prime} \mathrm{W}\right.$; granodioritic gneiss with granite sheets (Millar and Pankhurst, 1987)). The sorting, rounding and quartzose nature of the debris are consistent with a sedimentary source rock, not presently exposed any nearer to the sampling site than the Ellsworth Mountains.

Radar-sounding data from the ice column at Fox 4 are shown in Figure 3. Received power is plotted against depth, with two main reflection horizons marked, both of which have signals well above the noise. The first we assume to be from the interface between meteoric ice (derived from snowfall) and ice of marine origin (Thyssen and others, 1993), the interface showing up because of the slight salt content of the marine ice (Oerter and others, 1992). 'Marine ice' is found in several areas on the Ronne Ice Shelf, where basal freezing occurs rather than basal melting. Beneath an ice shelf, melting of deep basal ice can cause water to be cooled well below the surface pressure-freezing point. Where this very cold water rises up a basal incline, the decreasing pressure, and consequent increase in the local freezing point, causes the formation of ice crystals in the water column, which accumulate at the ice-shelf base. In some parts of the ice shelf the resulting layer of accreted marine ice constitutes over half the total ice column (Thyssen and others, 1993; Lambrecht and others, 2007). 


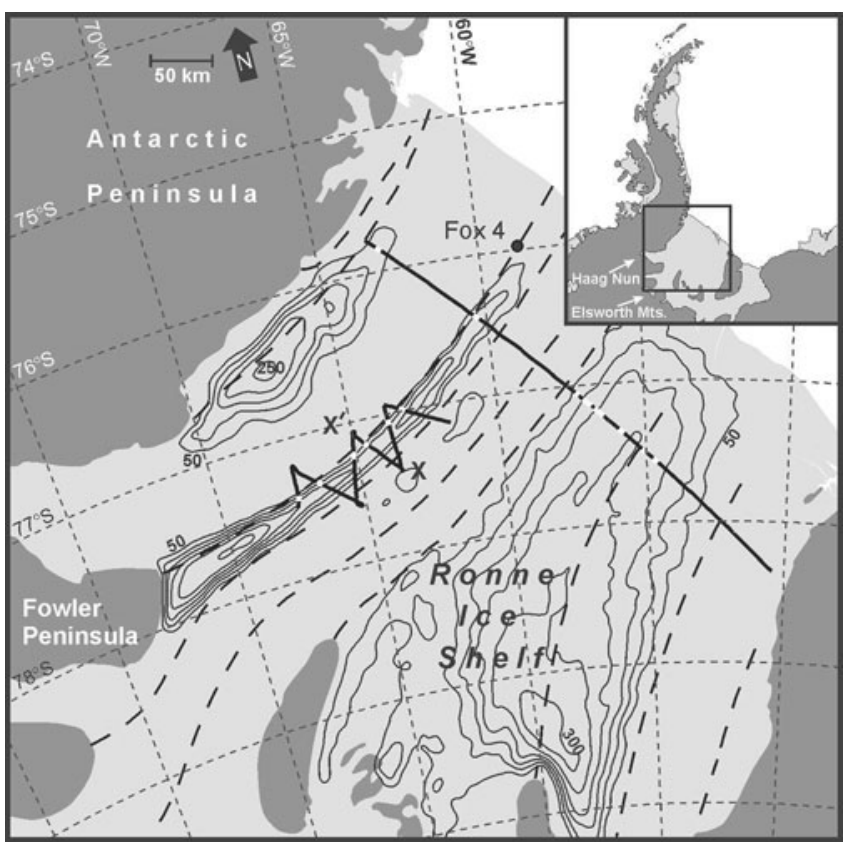

Fig. 1. Map showing the Ronne Ice Shelf. The contours show the thickness of marine ice, with contour levels starting at a value of $10 \mathrm{~m}$, with an interval of $50 \mathrm{~m}$. The scale bar represents a distance of $50 \mathrm{~km}$. The position of the drill site (Fox 4) is indicated, as is the (zigzag) 1995 radar flight track over the marine ice body upstream, with the locations of the strong reflector shown in white. The radar flight track from 1982 across the ice shelf is mapped, with those parts of the track showing anomalously strong returns from the marine-ice/meteoric-ice interface also highlighted in white. The flow traces (dashed lines) were derived from satellite imagery.

The map in Figure 1 shows that the drill site is near the boundary of a marine ice region. As the debris was found at a depth between the two coring attempts (210 m and $310 \mathrm{~m}$ ), we assume that it was located at the depth of the first of the two horizons indicated in Figure 3. The second horizon is weak but well defined, and came from the base of the ice shelf, its depth corresponding well with the total ice-shelf thickness measured after drilling.

\section{SOURCE OF THE DEBRIS}

Flow traces mapped from satellite imagery are shown in Figure 1. They record the route that ice has taken across the ice shelf, and suggest that the debris sampled at Fox 4 has been transported from Fowler Peninsula. Such a source is consistent with the geological similarity to material from Haag Nunataks.

There is more than one possible mechanism for the introduction of rock debris at the base of the ice shelf. Given appropriate topography, ascending cold water that is in contact with the sea-floor can become supercooled and form anchor ice on rock debris, ultimately lifting it to the ice base (Swithinbank, 1968). It is also possible that conditions at the base of neighbouring ice streams favour basal freezing. Christofferson and others (2010) report observations of around $2 \mathrm{~m}$ of rock material within the deepest $15 \mathrm{~m}$ or so of Kamb Ice Stream.

Hulbe (1997) pointed out that if marine ice accretion begins sufficiently soon after ice has gone afloat, and before basal melting has had a chance to remove any debris-laden basal ice, then that debris will become encased within the
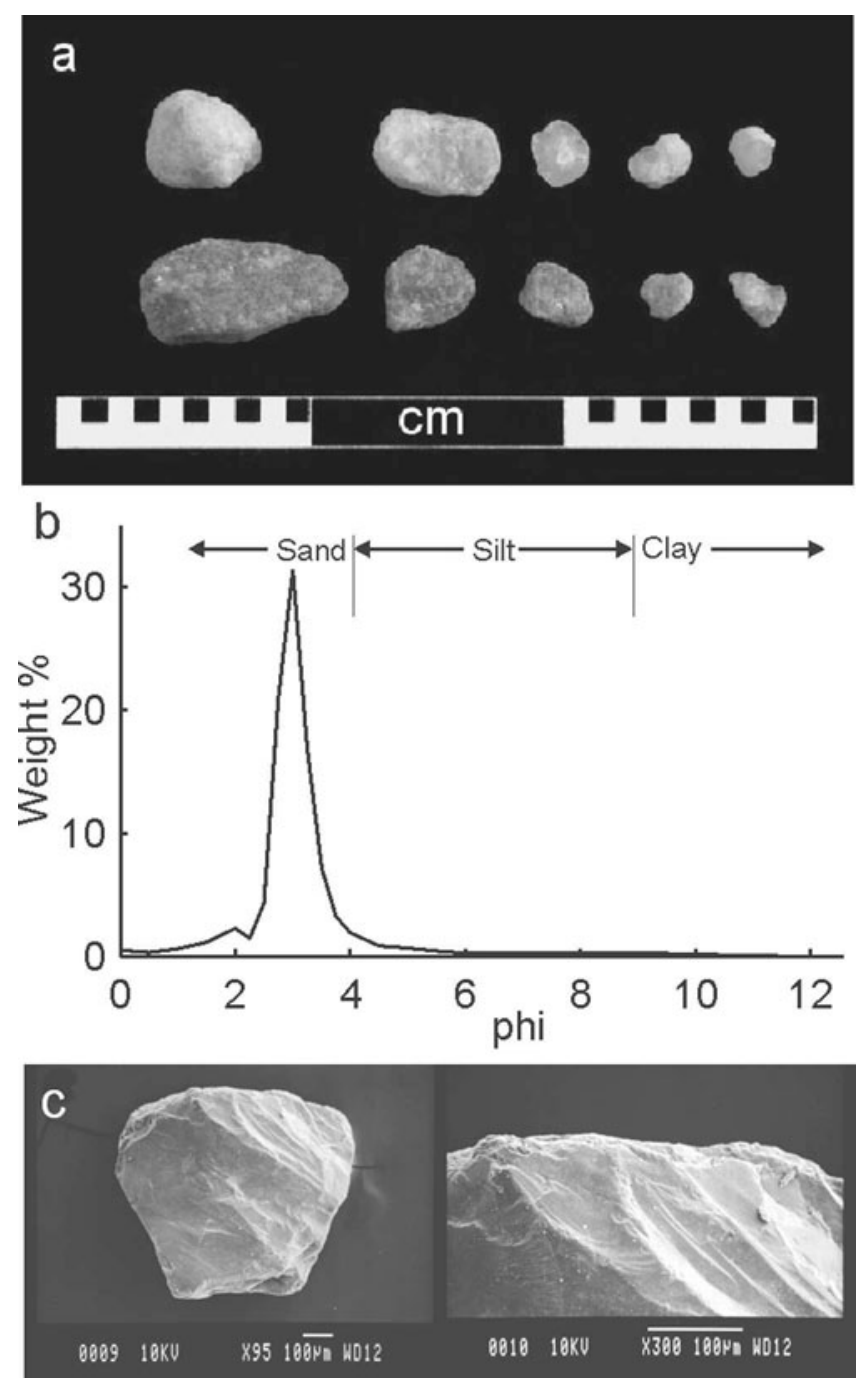

Fig. 2. (a) The ten gravel grains: the upper row are quartzites, the lower row feldspathic and lithic sandstones. Note that all grains are rounded. (b) Grain-size distribution of sand (measured by sieving) and mud (measured by Malvern Mastersizer). (c) Scanning electron micrographs of a typical coarse sand grain showing a stepped surface and edge abrasion, considered typical of brittle fracture during subglacial transport (Sharp and Gomez, 1986; Mazzullo and Anderson, 1987).

ice shelf. In the case of Fowler Peninsula, ice flowing past either side of the peninsula (Fig. 1) leaves a region of thinner ice in the peninsula's 'lee'. It is the upwelling of cold water into the basal depression caused by this thin ice region that results in rapid accumulation of marine ice, which then flows downstream as part of the ice shelf.

Two other mechanisms for introducing debris high in the ice shelf have been discussed in the literature. Anderson and others (1991) suggest that debris might be embedded within the Ronne Ice Shelf because of the presence of converging ice streams. In this case the inclusions would take the form of septa, commonly seen as dark lines striking vertically through icebergs. Other possible sources of septa are basal crevasses found at ice-stream shear margins (Catania and others, 2006) that might become filled with sediment (personal communication from Ted Scambos, 2012). The principal difference between including debris in a septum and at the ice base would be how far up into the ice shelf the debris reaches. Noting the absence of 


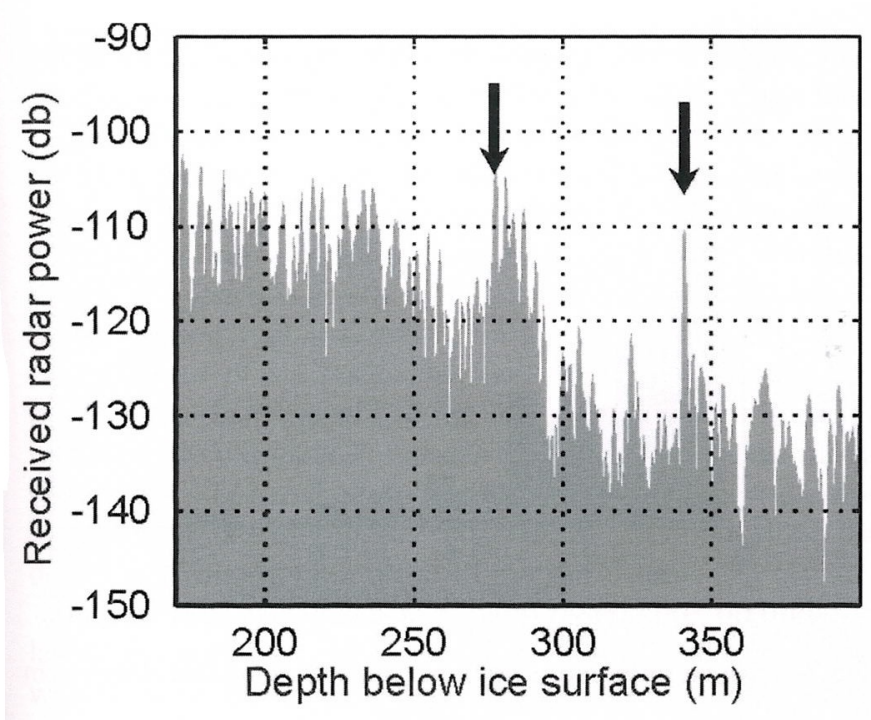

Fig. 3. Radio-echo data obtained from Fox 4. The first arrow indicates the meteoric/marine ice boundary and debris; the second arrow shows the return from the ice base.

well-defined hyperbolas in radargrams across the marine ice body (see below), and the fact that the material was found at the depth of the top of the marine ice body (and not shallower), we assume that the debris we sampled is not contained in a septum.

\section{DISTRIBUTION OF THE DEBRIS}

An airborne downward-looking radar campaign conducted in 1995 surveyed the marine ice body associated with Fowler Peninsula. Figure 4 shows a radargram from one of the six transits crossing the ice body. The strong returns at either end of the track are from the ice-ocean interface at the base of the ice shelf on either side of the area of marine ice. The much weaker, englacial return indicates the interface between meteoric and marine ice. There is no return from the interface between marine ice and the underlying water: the absorption of radar by marine ice is too great for the basal return to be detectable.

The radar data also show a narrow band ( $\sim 4 \mathrm{~km}$ wide) of very strong returns from the depth of the meteoric/marine ice boundary at the western side of the marine ice body. The band lies at a depth within the ice shelf $(\sim 280 \mathrm{~m})$ similar to that of the internal return seen at Fox 4 (Fig. 3). Along the flowline between the radar transit of the marine ice and the drill site, the depth of the meteoric-marine ice interface is expected to be approximately constant: the vertical motion of the interface resulting from snow accumulation is balanced by the thinning due to vertical strain in the ice column (Jenkins and Doake, 1991). We therefore suggest that the englacial feature observed in the radar data from the drill site relates to the western edge of the bright section of return seen at a similar depth in the 1995 radar transit. The locations of the bright band found in each of the six airborne radar transits of the marine ice body are shown in Figure 1. In addition, we conjecture that basal debris is the cause of the bright radar return.

Figure 5 shows a satellite image with a stretched greyscale that indicates the route of the debris-containing ice column. The ice that passes through the location of the drill site passes 1 or $2 \mathrm{~km}$ to the west of the bright englacial

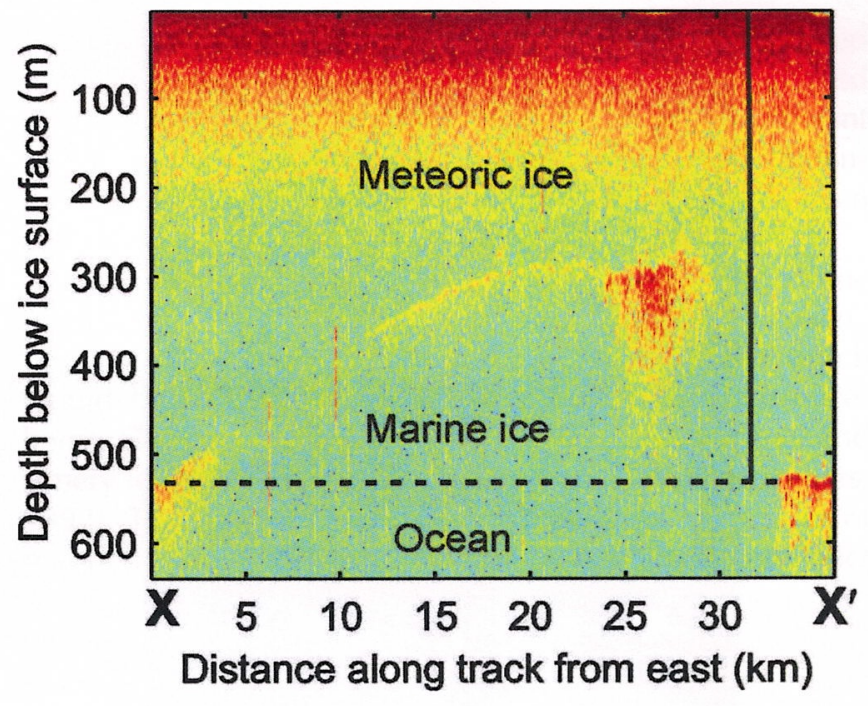

Fig. 4. Radio-echo data from one of the airborne transits of the marine ice body ( $\mathbf{X}-\mathbf{X}^{\prime}$ in Fig. 1). The colour shows echo strength, with red corresponding to a strong signal. The vertical black line indicates the location of the intersection with the flowline that passes through Fox 4.

radar returns (indicated in Fig. 4), and in a region where no echo is detectable. The marine ice area is thought to extend as far west as the recommencement of the strong return from the ice-ocean interface and we assume that the marine ice interface is obscured by buried crevassing in the upper layers of the ice shelf. It is possible therefore that the debris is not connected with the bright radar reflector, although, on the flowline for which the airborne radar detected nothing, the ground-based radar succeeded in detecting what we have interpreted to be an echo at the marine ice interface, as well as a return from the marine ice-ocean interface.

\section{DEBRIS FLUX}

Although the strength of the radar return in the 1995 radar data provides no quantitative evidence as to the amount of material present, it can provide some insights into the nature of the reflecting layer. Oerter and others (1992) showed that the marine ice at the interface between marine and meteoric ice types was characterized by a higher concentration of particulates, smaller crystal size and a maximum in ice salinity. We cannot be certain of the salt content of the marine ice beneath the ice-rock matrix downstream of Fowler Peninsula; however, if we assume that the conductivity of the ice is the same as was measured for the marine ice sampled at the interface by Oerter and others (1992) (Moore and others, 1994), and we use a mixture formula (Kärkkäinen and others, 2001) to calculate the permittivity of the ice-rock matrix, we can derive an estimate of the debris concentration needed to explain the observed reflection coefficient. A histogram of debris volume concentration calculated in such a way is given in Figure 6, showing a modal value of $5-10 \%$. Formally, this calculation assumes that the interfering wave returned from the deeper interface (the interface between the ice-rock mixture and marine ice) has a negligible effect on the measured reflection coefficient.

An alternative model is that the bright reflectors, which originate on the eastern side of Fowler Peninsula, are not, in fact, connected with the debris sampled at Fox 4, which 


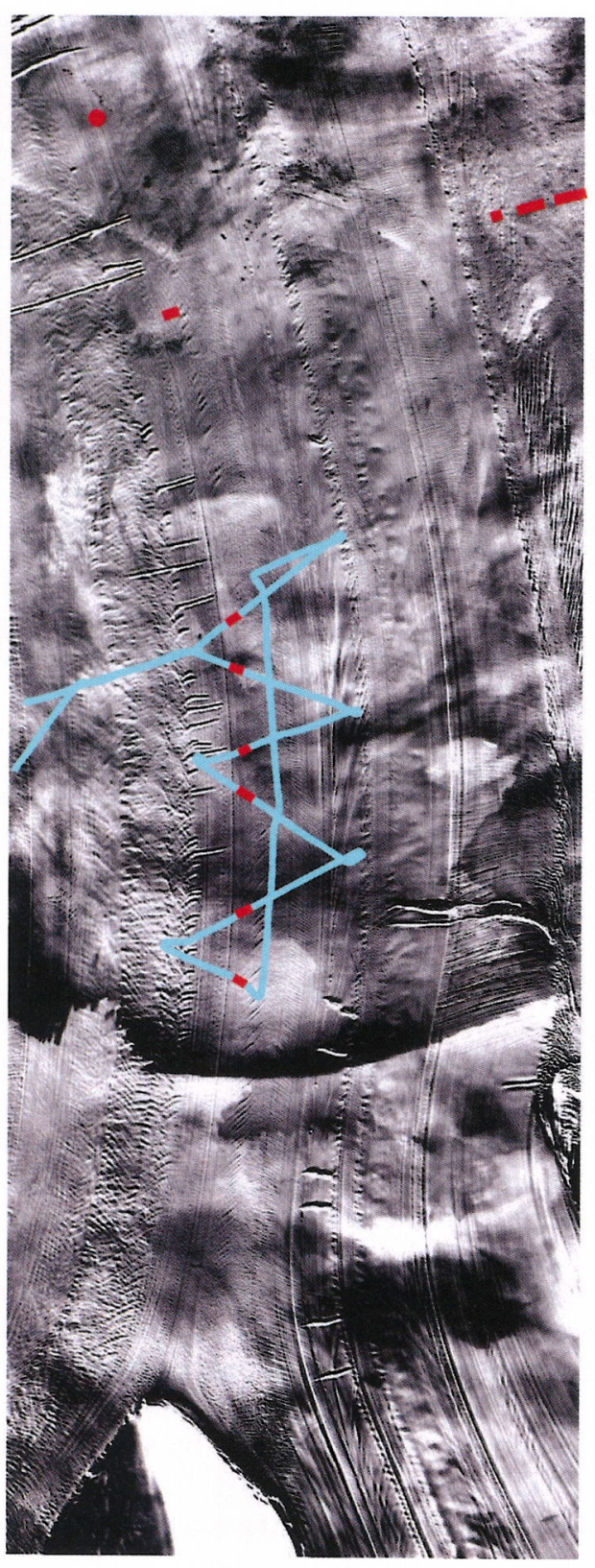

Fig. 5. Satellite image rendered to highlight the surface features, and indicate the route and likely source of the debris found at Fox 4 (red dot at top of picture). The radar flight-line is shown in cyan, with the red portions indicating the location of bright reflectors. Bright reflectors in one of the 1982/83 flight-lines are also shown. Fowler Peninsula is visible at the bottom of the picture.

appears to originate from the very tip of the peninsula. The bright returns are unlikely to result from buried crevasses, as these would be expected to be at $\sim 140 \mathrm{~m}$ depth, according to Jenkins and Doake's (1991) modelling of the nearby Rutford flowline. A possibility is that they result from very much more saline water freezing in basal crevasses, although we would expect to see more evidence of hyperbolas in the radargram. For marine ice freezing on to the base to have a conductivity high enough to produce the anomalously bright radar returns, it would need to have salinities approaching that of sea ice, such as that found frozen to the base of the Ross Ice Shelf at J-9 (Zotikov and others, 1980), and it would be difficult to explain the sharp spatial boundaries of the bright returns - why the highly saline ice suddenly gives way to marine ice.

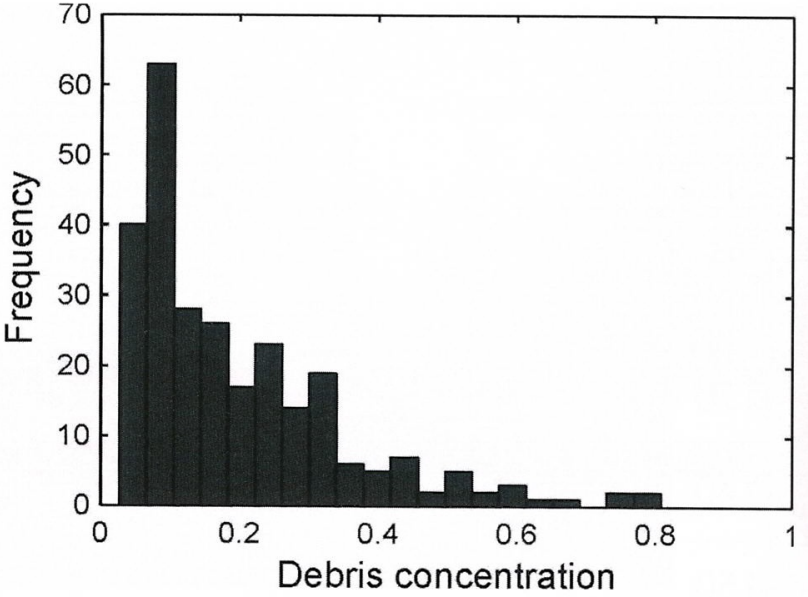

Fig. 6. Histogram of debris volume concentrations calculated from the radar reflection coefficients.

For the purposes of this discussion we proceed under the original assumption that the presence of the debris causes the bright radar returns. To determine how widespread the distribution of debris might be, and ultimately to obtain some bounds on the total amount of debris melting out of the ice shelf, we reviewed the data from the many airborne radar missions flown across the ice shelf during the early 1980s (Crabtree and Doake, 1986). One of the tracks is indicated in the map in Figure 1. In total, about $45 \mathrm{~km}$ (or $10 \%$ ) of the track length in Figure 1 shows bright reflectors at the meteoric/marine ice boundary.

No direct measure of the thickness of debris-laden ice is available. The band is many ice thicknesses in width, so the difference in density between ice and debris would be expected to create a depression in the surface of the ice shelf (Van der Veen and Whillans, 1989). However, the variability in ice surface elevation, presumably for dynamical reasons, is about $1 \mathrm{~m}$ at spatial wavelengths of around the width of the band, and surface elevations measured during the radar flights show no discernible hydrostatic depression that can be unambiguously attributed to the debris band itself. We would expect to be able to detect a surface elevation signature if a consolidated debris layer thickness of more than about $0.5 \mathrm{~m}$ were present. Debris-laden icebergs have been observed with bands of $5 \%$ debris by weight (or approximately $2 \%$ by volume), some $5-15 \mathrm{~m}$ thick (Anderson and others, 1980), but we are unaware of observations of icebergs with marine ice ('green' icebergs) with debris at the interface between the marine and meteoric ice. For a mean seaward motion of $\sim 1 \mathrm{kma}^{-1}$ along the line of the flight track and using an upper limit of $\sim 10 \mathrm{~m}$ as the thickness of the debris layer at $5 \%$ volume concentration, the total volume of debris-laden ice melting into the cavity would be $\sim 5 \times 10^{8} \mathrm{~m}^{3} \mathrm{a}^{-1}$; and for an average melt rate of $\sim 1 \mathrm{ma}^{-1}$ (Joughin and Padman, 2003), the area raining debris into the cavity would be $\sim 450 \mathrm{~km}^{2}$.

\section{DISCUSSION AND CONCLUSIONS}

When an ice shelf goes afloat, any rock debris incorporated at its base can remain trapped within the ice shelf by basal freezing, provided that the freezing begins before the debrisbearing ice has been melted out. The particle paths for the lower part of the ice column then have an upward 
component. Although areas of intense freezing are often small in extent (Bombosch and Jenkins, 1995), they can lead to the deposition of marine ice hundreds of metres thick, with the potential to bury the debris well up within the ice shelf. As the ice flows towards the ice front the oceanographic regime typically changes to melting conditions. Where the debris is finally melted out depends on the rate of basal melting that the ice column experiences, the horizontal speed of ice shelf-flow, and the distance to the ice front. If the debris is still in the ice shelf at the ice front, it will be exported as IRD. Otherwise the meltout takes place within the sub-ice-shelf cavity and, given constant glaciological and oceanographic conditions, the deposition of debris will always take place in the same area.

In the case of the Fox flowline discussed here, up until the last major iceberg calving event of 2000 all the marine ice would have been expected to have melted off before reaching the ice front, resulting in debris building at a well-defined location in the sub-ice-shelf cavity. This can be used to adjust our limit on the amount of consolidated debris within the ice column. Between Fox 4 and the present ice front, the water column thickness varies from 200 to $300 \mathrm{~m}$ (Nicholls and others, 2004). If the conditions, both glaciological and oceanographic, have remained largely unchanged for the last several thousand years, our upper limit of $0.5 \mathrm{~m}$ of consolidated debris must be substantially reduced, otherwise the water column in the area of deposition would have been displaced by sediment within a few thousand years.

The prospect of high deposition rates at well-defined locations within a sub-ice-shelf cavity is intriguing. An ice shelf that carries a substantial load of debris might have a stable configuration only if that debris is lost in icebergs. If the ice shelf advances far enough for the debris to begin raining out within its cavity, the change in sea-floor topography will cause substantial changes to the local ocean dynamics, with consequential changes in the ocean's interaction with the ice shelf. It might even be possible for an ice rise to form.

For the Ronne Ice Shelf, present-day areas of deposition can be mapped by overlaying the flowlines that pass through the debris deposits, as identified in the radar records, on the map of marine ice (e.g. Fig. 1). The intersection of the flowlines with the seaward edge of the marine ice distribution, that is, where the last of the marine ice is being melted off, indicates the areas of deposition. Studying the sediments at the ice front, coupled with determining the pattern of deposition beneath the ice shelf using oversnow seismics, would potentially provide a control on the history of ice-ocean interactions: lower freezing rates/higher melt rates, for example, would lead to the debris melting out further upstream. If the rainout is detectable at the ice front, seismics surveys along the present-day (somewhat retreated) ice front should reveal historical shifts in the lateral position of flowlines.

There have been geophysical investigations, both shipbased work north of the ice front (Hübscher and others, 1996), and ice-shelf based activities over the northern Ronne Ice Shelf (King and Bell, 1996), with a focus on deep crustal seismic studies. There is no obvious evidence from the shipbased seismic studies for anomalously rapid sedimentation at the end of the flowline, and the ice-shelf-based studies were west of the marine ice area. A series of sediment cores have been recovered off the Ronne Ice Front. The majority were not near where the debris might have been deposited in the past, although one surface grab sample was aligned with the Fox 4 flowline. This sample showed different sedimentation for this part of the ice front section, dominated by sands with varying amounts of dropstones and even cobbles (Haase, 1986).

Had the geometry of the embayment in which the Ronne Ice Shelf floats been even quite subtly different the calving line could have been significantly further south, which would have allowed the production of debris-laden icebergs. Other Antarctic ice shelves, notably the Filchner and Amery ice shelves, shed 'green icebergs' (Oerter and others, 1992). These are icebergs that retain a substantial layer of marine ice, and, therefore, any debris load at the meteoric/ marine ice interface. Alternatively, a cooling in the ocean would reduce melt rates near the ice front and could also cause the Ronne to switch to being an IRD-layer-producing ice shelf. However, the apparent absence from the Weddell Sea of any extensive and well-correlated IRD layers over the past 100000 years (Ó Cofaigh and others, 2001) suggests that there have never been extended intervals in which the Ronne Ice Shelf has been a source of IRD-bearing icebergs.

\section{ACKNOWLEDGEMENTS}

We are grateful to Ted Scambos and two anonymous reviewers for insightful comments that significantly improved the manuscript.

\section{REFERENCES}

Anderson JB, Domack EW and Kurtz DD (1980) Observations of sediment-laden icebergs in Antarctic waters: implications to glacial erosion and transport. J. Glaciol., 25(93), 387-396

Anderson JB, Kennedy DS, Smith MJ and Domack EW (1991) Sedimentary facies associated with Antarctica's floating ice masses. In Glacial marine sedimentation; paleoclimatic significance. Geological Society of America, Boulder, CO, 1-25 (GSA Special Paper 261)

Benn DI and Ballantyne CK (1994) Reconstructing the transport history of glaciogenic sediments: a new approach based on the co-variance of clast form indices. Sediment. Geol., 91(1-4), 215-227

Bombosch A and Jenkins A (1995) Modeling the formation and deposition of frazil ice beneath Filchner-Ronne Ice Shelf. J. Geophys. Res., 100(C4), 6983-6992

Catania GA, Conway H, Raymond CF and Scambos TA (2006) Evidence for floatation or near floatation in the mouth of Kamb Ice Stream, West Antarctica, prior to stagnation. J. Geophys. Res., 111(F1), F01005 (doi: 10.1029/2005JF000355)

Christoffersen P, Tulaczyk S and Behar A (2010) Basal ice sequences in Antarctic ice stream: exposure of past hydrologic conditions and a principal mode of sediment transfer. J. Geophys. Res., 115(F3), F03034 (doi: 10.1029/2009JF001430)

Crabtree RD and Doake CSM (1986) Radio-echo investigations of Ronne Ice Shelf. Ann. Glaciol., 8, 37-41

Haase GM (1986) Glaciomarine sediments along the Filchner/ Ronne Ice Shelf, southern Weddell Sea. First results of the 1983/ 84 Antarktis-2/4 Expedition. Mar. Geol., 72(3/4), 241-258

Hübscher C, Jakat W and Miller H (1996) Structure and origin of southern Weddell Sea crust: results and implications. In Storey $\mathrm{BC}$, King EC and Livermore RA eds. Weddell Sea tectonics and Gondwana break-up. The Geological Society, London, 201-211 (Geological Society Special Publication 108)

Hulbe CL (1997) An ice shelf mechanism for Heinrich layer production. Paleoceanography, 12(5), 711-717 
Jenkins A and Doake CSM (1991) Ice-ocean interaction on Ronne Ice Shelf, Antarctica. J. Geophys. Res., 96(C1), 791-813

Joughin I and Padman L (2003) Melting and freezing beneath Filchner-Ronne Ice Shelf, Antarctica. Geophys. Res. Lett., 30(9), 1477-1480 (doi: 10.1029/2003GL016941)

Kärkkäinen K, Sihvola A and Nikoskinen K (2001) Analysis of a three-dimensional dielectric mixture with finite difference method. IEEE Trans. Geosci. Remote Sens., 39(5), 1013-1018 (doi: 10.1109/36.921419)

King EC and Bell AC (1996) New seismic data from the Ronne Ice Shelf, Antarctica. In Storey BC, King EC and Livermore RA eds. Weddell Sea tectonics and Gondwana break-up. The Geological Society, London, 213-226 (Geological Society Special Publication 108)

Lambrecht A, Sandhager H, Vaughan DG and Mayer C (2007) New ice thickness maps of Filchner-Ronne Ice Shelf, Antarctica, with specific focus on grounding lines and marine ice. Antarct. Sci., 19(4), 521-532 (doi: 10.1017/S0954102007000661)

Mazzullo J and Anderson JB (1987) Grain shape and surface texture analysis of till and glacial marine sand grains from the Weddell and Ross Seas, Antarctica. In Marshall JR ed. Clastic particles: scanning electron microscopy and shape analysis of sedimentary and volcanic clasts. Van Nostrand Reinhold, New York, 314-327

Millar IL and Pankhurst RJ (1987) Rb-Sr geochronology of the region between the Antarctic Peninsula and the Transantarctic Mountains: Haag nunataks and Mesozoic granitoids. In McKenzie GD ed. Gondwana Six: structure, tectonics, and geophysics. American Geophysical Union, Washington, DC (Geophysical Monograph Series 40), 15-160

Moore JC, Reid AP and Kipfstuhl J (1994) Microstructure and electrical properties of marine ice and its relationship to meteoric ice and sea ice. J. Geophys. Res., 99(C3), 5171-5180 (doi: 10.1029/93JC02832)

Nicholls KW, Makinson K and Østerhus S (2004) Circulation and water masses beneath the northern Ronne Ice Shelf, Antarctica. J. Geophys. Res., 109(C12), C12017 (doi: 10.1029/ 2004JC002302)

Ó Cofaigh C, Dowdeswell JA and Pudsey CJ (2001) Late Quaternary iceberg rafting along the Antarctic Peninsula continental rise and in the Weddell and Scotia Seas. Quat. Res., 56(3), 308-321 (doi: 10.1006/qres.2001.2267)

Oerter $\mathrm{H}$ and 6 others (1992) Evidence for basal marine ice in the Filchner-Ronne Ice Shelf. Nature, 358(6385), 399-401 (doi: 10.1038/358399a0)

Rignot E and Jacobs SS (2002) Rapid bottom melting widespread near Antarctic ice sheet grounding lines. Science, 296(5575), 2020-2023

Sharp M and Gomez B (1986) Processes of debris comminution in the glacial environment and implications for quartz sand-grain micromorphology. Sediment. Geol., 46(1-2), 33-47

Swithinbank C (1968) Ice movement in the McMurdo Sound area of Antarctica. IASH Publ. 86 (Symposium at Hanover, New Hampshire - Antarctic Glaciological Exploration (ISAGE)), 472-487

Thyssen F, Bombosch A and Sandhäger H (1993) Elevation, ice thickness and structure mark maps of the central part of the Filchner-Ronne Ice Shelf. Polarforschung, 62(1), 17-26

Van der Veen CJ and Whillans IM (1989) Force budget: I. Theory and numerical methods. J. Glaciol., 35(119), 53-60

Zotikov IA, Zagorodnov VS and Raikovsky JV (1980) Core drilling through the Ross Ice Shelf (Antarctica) confirmed basal freezing. Science, 207(4438), 1463-1465 